\title{
1 The role of filter-feeding Asian carps in algal dispersion
}

2

3 Judit Görgényi ${ }^{1^{*}}$, Gergely Boros $^{2}$, Zoltán Vitál², Attila Mozsár ${ }^{2}$, Gábor Várbíró1, 4 Gábor Vasas ${ }^{3}$, Gábor Borics ${ }^{1}$

$5 \quad{ }^{1}$ Department of Tisza Research, MTA Centre for Ecological Research,18/c Bem square, H-4026 6 Debrecen, Hungary

$7 \quad{ }^{2}$ Balaton Limnological Institute, MTA Centre for Ecological Research, 3. Klebelsberg Kuno street, H-

Keywords: phytoplankton, digestibility, biogeography, Asian carps

\section{Abstract}

The gut contents of filter-feeding fish often contain considerable amounts of viable phytoplankton cells, thus these animals can act as vectors and may play an important role in the horizontal and vertical transport of algae. In this study, the potential role of the introduced filter-feeding Asian carps (hybrids of silver carp Hypophthalmichthys molitrix and bighead carp $H$. nobilis) in algal dispersion was studied in the oligo-mesotrophic Lake Balaton (Hungary). We examined the algal composition in the lake water, gut-contents (foregut and hindgut) and occasionally in the filtered suspensions collected directly from the gill rakers (filtering apparatus) of fish. Microscopic analyses revealed that the phytoplankton composition of the ingested food differed considerably from what we found in the lake water. Cryptophytes, dinoflagellates and euglenophytes were observed in both the lake water and 
foregut samples, but were absent in the hindgut samples. However, in the cultured hindgut samples we found viable cells of several phytoplankton taxa (e.g., diatoms, blue-greens, desmids, volvocalean and chlorococcalean green algae), which managed to survive the physical and chemical digestion. Thus, it can be concluded that Asian carps can be potential vectors of phytoplankton and facilitate their dispersal. These results imply that the presence of these filter-feeding fish can alter the phytoplankton species composition and promote the dominance of taxa that are able to resist digestion.

\section{Introduction}

Capability of dispersion is among the most important features of all living organisms that enable them to colonize new habitats and increase their evolutionary success (Cox \& Moore, 1993). Even though there are some endemic algal taxa typical for isolated areas, the majority of phytoplankton species have a widespread occurrence, which could be attributed mainly to their ability to travel over large distances. Algae are mainly dispersed passively by water currents, by air, by animals or by accidental human activities (Chrisostomou et al., 2009; Genitsaris et al., 2011; Padisák, 2004). There are some taxa (e.g., species in the Chlorophyta, Cyanobacteria, Chrysophyta groups), which are able to survive travelling in a humid medium (i.e., in aerosols or on the wet surfaces of animals), without developing specialized protective structures (Van Overeem, 1937; Brown et al., 1964). However, to cope with unfavorable external conditions, several phytoplankton species develop akinetes, cysts or thick-walled structures enabling algae to be effectively dispersed even on dry surfaces (Padisák, 2004).

Another possible way of active algal dispersal is the moving in aqueous media. This process does not involve the risk of dehydration, but if it occurs within the alimentary tract of a fish, algae are exposed to the effects of digesting fluids. Accordingly, the capability of 
species to resist digestion is a significant factor in determining the survival and ultimately the dispersal success of algae (Miura \& Wang, 1985; Vörös et al., 1997). Despite fish are less motile and able to travel slower than waterfowls for instance, they can also be important vectors of algae and serve as low-distance carriers in aquatic ecosystems.

To improve the water quality and increase fishery yields, filter-feeding silver carps (Hypophthalmichthys molitrix), bighead carps (H. nobilis), and their hybrids (collectively known as filter-feeding Asian carps) have been introduced into eutrophic lakes and rivers throughout the world since the early 1950s (Jennings 1988; Kolar et al. 2007). Consequently, Asian carps became key species in freshwater biomanipulation (Datta \& Jana, 1998; Zhang et al., 2008; Zeng et al., 2014), and several studies were published on the ecological role of these fish, including their impacts on the functioning of aquatic food webs (Borics et al., 2013), or their capability to digest planktonic organisms (Spataru, 1977; Vörös et al., 1997; Herodek et al., 1989; Tátrai et al., 2006). The general approach regarding Asian carp stocking has changed considerably in the past decade, because a number of recent studies have demonstrated that the presence of these fish outside their native range involves ecological risks, including the deterioration of water quality and strong interspecific food competition with native fish species (Sampson et al., 2009; Lin et al., 2014).

Introduction of Asian carps to Hungarian waters started in the 1960s. They were stocked into small artificial ponds (Borics et al., 2000), as well as into natural lakes (Boros et al., 2014). During the decades, Asian carps became successful invaders in different types of aquatic habitats in Hungary and nowadays can be considered as the most efficient plankton consumers in the freshwaters of this region. Lake Balaton was stocked with Asian carps between 1972 and 1983. The stocking was stopped and banned thereafter because this intervention did not result in any significant improvement in water quality. Yet, the Asian 
carp biomass is still high in the lake, constituting about 30\% of the total fish biomass (Tátrai et al., 2009). The population is dominated by hybrid individuals (Boros et al., 2014).

In this study, we aimed at examining the potential role of filter-feeding Asian carps in algal dispersion. More specifically, we studied the algal composition in the lake water, in the gut contents (foregut, hindgut) and occasionally in the filtrated suspension (collected from the gill rakers of Asian carps), focusing on the identification of algae species that remain viable after passing through the alimentary tract.

We hypothesized that algae having thick gelatinous substance around the cells or robust cellulose cell wall can cope successfully with the different physical and chemical digesting processes. We also hypothesized that smaller-sized taxa are more exposed to digesting effects of intestinal fluids, because of their larger surface to volume ratio. Thus, we expected that their survival rate in the alimentary tract is smaller compared to that of larger-sized taxa.

\section{Methods}

\section{Study area}

Lake Balaton (latitude: $47^{\circ} 3^{\prime} 50^{\prime \prime}-46^{\circ} 42^{\prime} 6^{\prime \prime}$, longitude: $17^{\circ} 14^{\prime} 58^{\prime \prime}-18^{\circ} 10^{\prime} 28^{\prime \prime}$ ) is the largest shallow lake in Central Europe, located in Hungary. The lake has a surface area of 596 $\mathrm{km}^{2}$ and an average depth of about 3 meters (Istvánovics et al., 2007). The lake had been suffering from serious eutrophication and cyanobacterial blooms for several decades, but the water quality has since improved due to the restoration efforts, and now the lake is oligomesotrophic (Tátrai et al., 2008).

\section{Collection of fish, gut content and gill raker filtrate samples and lake water for microscopic} analyses 
To explore the feeding habits of Asian carps, five samplings were conducted between April-October 2013. Fish were sampled from the eastern basin of Lake Balaton with $12 \mathrm{~cm}$ mesh-size gill nets. Altogether 46 Asian carps were collected (9-12 fish per sampling). Fish were transported to the laboratory after catching (within $30 \mathrm{~min}$ ) and were dissected immediately to obtain the foregut and hindgut contents. Foregut samples were collected from the anterior end of intestines (a $10-15 \mathrm{~cm}$ long section starting from the oesophagus), while hindgut samples were collected from the posterior end of the alimentary tract $(0-15 \mathrm{~cm}$ from the anus). Alternatively, when we did not find sufficient amount of material in the foreguts, gill raker filtrate samples were collected from the sulcus of the epibranchial organ, which is a groove within the gill arch where the filtered matter is concentrated before ingestion. The compressed filtrates were scraped off from the inner surface of gill rakers with a flat stick (Fig. 1). The collected samples were stored in dry and cold place until sample processing, which was performed within 1 hour. All samples for microscopic phytoplankton analyses were preserved in diluted Lugol's solution, while samples for culturing were stored in sterile vessels and were not treated with any chemicals. These samples were kept in darkness at $0-4^{\circ} \mathrm{C}$ for no longer than $24 \mathrm{~h}$ before culturing.

To determine phytoplankton species composition in Lake Balaton, water samples were collected from the entire water column with a tube-sampler at each fish sampling date. Three subsamples were taken at different locations of the study area, typically in the proximity of the fishing net. These three samples were mixed right after samplings.

Subsamples for additional zooplankton and detritus analyses were also preserved in Lugol's solution, but these results are not detailed in this study. 
Analysis of phytoplankton composition

\section{Phytoplankton samples}

The preserved phytoplankton samples were placed in $5 \mathrm{~mL}$ sedimentation chambers (Hydrobios, Kiel) and were left to settle for $24 \mathrm{~h}$. The identification of phytoplankton species was carried out using Zeiss Axioimager A2 research microscope. Determination of relative percentage abundances were performed with an inverted microscope (ZEISS Axiovert-40 CFL), following Utermöhl's (1958) method. In all cases, a minimum of 400 specimens per sample were counted at $400 \times$ magnification. For the characterization of phytoplankton, both abundance and occurrence data were used. Identification of species was performed according to Ettl, 1978; Förster, 1982; Hofmann et al., 2011; Huber-Pestalozzi, 1950, 1955, 1961; Komárek \& Anagnostidis, 1998, 2005; Komárek \& Fott, 1983; Krammer, 2003; Krammer \& Lange-Bertalot, 1986-1991; Popovsky \& Pfiester, 1990 and Starmach, 1985.

\section{Gut contents}

Phytoplankton was identified using an inverted microscope (ZEISS Axiovert-40 CFL). Samples of suitable density were placed in $1 \mathrm{ml}$ counting chambers (Hydrobios, Kiel) and allowed to settle for at least 24 hours. High-density samples were diluted with distilled water $(10 \times, 20 \times, 25 \times$ dilutions were applied, depending on the density). Estimations of cell concentrations and identifications were made either by counting the whole chamber at $400 \times$ magnification or by counting two or more transects. At least 400 individuals were counted. The identified taxa were classified into 12 main groups, following the taxonomic categorization of Van den Hoek et al. (1995) (Table 1). Diatoms and blue-green algae were not homogenous regarding their morphology, so these taxa were divided into further subgroups. To study the importance of size on the survival during the passage through the 
digestive tract, phytoplankton taxa were categorized into 3 groups based on their longest diameter $(<10 \mu \mathrm{m}, 10-40 \mu \mathrm{m}$ and $>40 \mu \mathrm{m})$.

\section{Culturing}

The hindgut material consists of various inorganic particles, dead and living organic compounds. Besides the microscopic investigation of this material is a really challenging task, viability of the organisms cannot be demonstrated by this method. Thus, the hindgut samples were cultured. It is important to note, that there is no "general" culturing medium which would be suitable to check the viability of all the phytoplankton groups in the hindgut. Therefore, prior to the investigations, we made preliminary studies, and tested several media (Jaworski’s, Allen's media, diatom-, euglena specific media, BG-11), among which the BG11 was found to be the best for our purposes. Although BG-11 gives an advantage to cyanobacteria, other taxa (Chlorococcalean green algae and diatoms) grew much better in this medium than in other offered genera-specific media. In addition, the species that proved to be viable in this medium were identical with those we observed during the microscopic observations of the hindgut material. To study the viability of cells in the hindguts, $100 \mu \mathrm{l}$ aliquots of hindgut samples were inoculated to blue-green medium (BG-11) and nitrogen free (BG) medium (Stanier et al., 1971). Each sample were grown in microtiter plate (with 24 well) in $2 \mathrm{ml}$ volume. Samples were incubated at $28^{\circ} \mathrm{C}$ and at $80 \mu \mathrm{mol} \mathrm{m} \mathrm{m}^{-2} \mathrm{~s}^{-1}$ light intensity for 10 days. After finishing the incubation for the microscopic analyses, the samples were fixed with Lugol's solution.

\section{Statistical analyses}

Kolmogorov-Smirnov tests and Levene's tests were used to estimate the normality of response variables and the homogeneity of variances. One-way ANOVA tests were used to compare the number of taxa in the three types of samples. When criteria of normality and 
homogeneity did not meet, Kruskal-Wallis ANOVA was applied. We used the STATISTICA 8.0 software for the statistical analyses, and decisions about the statistical significances were set at $p=0.05$ level. Differences between the three sample types were examined with nonmetric multidimensional scaling ordination (NMDS), based on Jaccard similarity index. The significant segregation of groups was tested by ANOSIM. We used PAST 3 software package for the analyses (Hammer et al., 2001).

\section{Results}

\section{Phytoplankton composition of Lake Balaton}

A total of 100 phytoplankton species were identified in the water samples taken from Lake Balaton, among which the Cyclotella ocellata had the highest relative abundance. Chrysochromulina parva and Rhodomonas cf. minuta also were abundant in the lake's phytoplankton samples (these results are not shown here).

Phytoplankton species were divided into 12 groups. Pennate diatoms and Chlorococcales spp. had the highest number of species in April, May, June and October. In September, colonial blue-greens and chlorococcalean green algae were the most species-rich taxa (Table 1). Regarding the species richness, there were no considerable differences in the numbers of species during the five sampling months (higher number of tychoplanktonic pennate diatoms was probably the consequence of water column mixing).

Regarding the relative abundances of counted units (cells or colonies) (Fig. 2), blue-greens, Chrysophyceae, diatoms, Cryptophyta, Chlorococcales and Volvocales occurred in relatively high percentage (>10\%) in Lake Balaton samples, while the relative abundance of Dinophyta, Euglenophyta and Desmidiales were less than 5\%. In April and June, Diatoms (April: 38.3\%, June: 40.8\%) and Chlorococcales (April: 33.9\%, June: 32.4\%), in May Chlorococcales (27 \%) and Cryptophyta (26.4\%), while in September and October diatoms (September: 56.7\%, 
October: 40.6\%) and blue-greens (September: $19.3 \%$, October: 16.6\%) had the highest relative abundance in the water column samples.

\section{Foregut contents}

In the samples taken from the foreguts, 138 phytoplankton species were found, among which (similarly to the water samples) the most frequent was the Cyclotella ocellata. Besides this, Aulacoseira sp. and Chroococcus sp. were also common species in the foreguts.

Pennate diatoms and chlorococcalean green algae had the greatest number of species in each month of the study period (Table 2). As for the total numbers of taxa, only slight differences were found, and similarly to the Lake Balaton samples the highest number of species was observed in June.

Regarding the relative abundances of counted units (cells or colonies) of the foregut samples, blue-greens, Chrysophyceae, diatoms and Chlorococcales species were dominant. Relative abundance of Dinophyta, Euglenophyta, Desmidiales, Volvocales and Cryptophyta taxa were less than 5\%. Diatoms (April: 54.4\%, May: 68.1\%, June: 49.8\%, September: 49.9\%, October: $60.1 \%$ ) and blue-greens (April: 26.8\%, May: 15.7\%, June: 29.1\%, September: 33\%, October: $27.1 \%$ ) were present in the highest percentage in the foregut samples (Fig. 3).

Significant difference $(\mathrm{p}>0.05)$ was found in the number of taxa between the Lake Balaton and the foregut samples (Fig. 4 a,b). More specifically, the taxa numbers of pennate diatoms, colonial blue-greens, Chlorococcales, Dinophyta and Euglenophyta species were higher in the foreguts. All other groups showed similar species richness in the lake and in the foregut samples.

Although there were several species which were found exclusively in Lake Balaton samples, surprisingly much more species were found in the foreguts, which were not found in the lake water samples (Table 3). 
Hindgut samples

226

In the cultured hindgut samples, 149 viable phytoplankton species were identified (Table 3). Nine of these species occurred in the cultured samples in all months of the study (Aulacoseira ambigua, Cyclotella ocellata, Fragilaria construens, Microcystis aeruginosa, Microcystis flos-aquae, Monoraphidium griffithii, Oocystis marssonii, Pediastrum boryanum and Scenedesmus denticulatus). We found 60 taxa, which were detected neither in the foregut, nor in the Lake Balaton, but were found in the hindgut samples (Table 3). As to the species richness of the larger algae groups, there were no considerable differences in the numbers of species during the study period. Pennate diatoms, chlorococcalean green algae and colonial blue-greens had the greatest number of species in each months (Table 4).

Significant difference was detected $(\mathrm{p}<0.05)$ in the number of species of colonial blue-greens, chlorococcalean green algae, Chrysophyceae and Cryptophyta groups between the Lake Balaton and hindgut samples (Fig. 4 a,b). When foregut and hindgut samples were compared, significant differences $(\mathrm{p}<0.05)$ were detected in the number of species in case of pennate diatoms, colonial blue-greens, Chlorococcales, Dinophyta, Euglenophyta and Cryptophyta groups (Fig. 4 a,b).

By comparing the taxa richness of the Lake Balaton and the hindgut samples, we found that pennate diatoms and chlorococcalean green algae were the most species-rich groups in both types of samples. However, the hindgut samples contained almost twice as many green algae and colonial blue-green species than the lake water samples (Fig. 5).

The proportion of groups in the foregut and hindgut samples differed remarkably from each other. Towards the hindgut, the number of chlorococcales and volvocalean green algae and both colonial and filamentous blue-green algae increased significantly $(\mathrm{p}<0.05)$. Cryptophyta and Dinophyta species were not detectable in the hindgut samples (Fig. 5). 
The NMDS ordination of samples also showed a clear separation of the three groups, thereby indicated significant differences in the algal composition between the three sample types (ANOSIM, p < 0.001) (Fig. 6).

\section{Size categories}

The three groups of samples contained an almost identical number of species in the smallsized taxa (Fig. 7). Taxa numbers in the middle and large-sized groups showed similar patterns, and both differed considerably in taxa numbers from the small-sized group.

\section{Discussion}

Due to the extensive global stocking that started in the 1950s, nowadays filter-feeding Asian carps have a widespread occurrence in the temperate regions all around the world, inhabiting almost all types of aquatic ecosystems. If we assume that planktivorious fish can be potential vectors of phytoplankton dispersal, then two questions should be answered: what kinds of algae are filtered, and what are digested by Asian carps? Both questions were examined profoundly in preceding studies. For instance, Porter (1973) divided phytoplankton to 3 distinct groups from the point of fish nutrition: non-available; available but non-digestible; and available and digestible. As for the availability, several studies addressed this topic, focusing mostly on the phytoplankton content of the foreguts. These studies have yielded controversial results. Some of them support the notion that silver carps cannot ingest algae smaller than $10 \mu \mathrm{m}$ (Hampl et al., 1983; Smith, 1989; Vörös et al., 1997), while others suggest that silver carps are able to collect even nannoplankton $(<10 \mu \mathrm{m})$ (Cremer \& Smitherman, 1980; Xie, 1999). This latter can be explained by the fact that gill rakers of silver carps are coated with mucus that facilitates filtering particles smaller than the gill-raker spacings (Lazzaro, 1987; Northcott \& Beveridge, 1988). Our results support this finding, 
because we found algae smaller than $10 \mu \mathrm{m}$ both in the foregut (Nitzschia sp., Oocystis sp., Phacus skujae, Rhodomonas minuta, Tetraedron minutum, Xanthophyceae sp., Centrales sp., Chlorococcales sp., Chrysophyceae sp., Cyclotella pseudostelligera) and in the hindgut (Achnanthes minutissima, Centrales sp., Chlorella sp., Chlorococcales sp., Choricystis minor, Chrysophyceae sp, Cyclotella pseudostelligera, Fragilaria pinnata, Lagerheimia balatonica, Monoraphidium irregulare, Trachydiscus sp.).

Another key factor of dispersion is the digestibility of algae, which plays also an important role in the success of biomanipulation and in the growth of fish. The high number of viable species found in the hindgut samples and their large morphological diversity imply that algae developed various types of adaptations that help their survival in the digestive tract. Several studies argued that the digestibility of phytoplankton by filter-feeding fishes is variable and depends on the structure and composition of the algal cell walls (Moriarty, 1973; Moriarty \& Moriarty, 1973). Some studies showed that colonial and filamentous blue-greens species that produce extracellular mucilage are able to remain viable after passing through the alimentary tract of filter-feeding fishes (Miura \& Wang, 1985; Vörös et al., 1997; Datta \& Jana, 1998; Lewin et al., 2003). Moreover, Gavel et al. (2004) demonstrated that larger Microcystis colonies were disintegrated during the passage through the digestive system of fish, but individual cells remained viable due to their mucilaginous coating. These results might serve as an explanation for the large number of viable blue-greens in the hindgut samples.

The thick cellulose cell wall might also protect algae from digestion. Bitterlich (1985) suggested that silver carps may not be able to meet their energy requirements consuming phytoplankton alone, most probably because the digestibility of some phytoplankton taxa is low (Dong et al. 1992) and gut fluids of silver carps lack cellulase enzyme to break down algal cell walls (Kolar et al. 2007). Thus, phytoplankton species with thicker cellulose cell walls are more likely to survive the passage through the guts. Among the viable taxa we found 
in the hindgut samples, chlorococcalean green algae and members of Xanthophyceae group have this type of cell-wall structure. Several studies demonstrated that viable cells of bluegreens, chlorococcalean green algae and Xanthophyceae not simply survived the passage through the digestive system of fish, but were able to take-up phosphorus from the gut content, which enhanced their growth after returning to water (Lewin et al., 2003; Kolmakov et al., 2006; Jancula et al., 2008). This can be explained by the fact that both the gelatinous cover and the thick cellulose cell wall can act as selective sieves, allowing small ionic compounds to enter, but impede the penetration of large molecules, such as digestive enzymes (Porter, 1976).

Although we hypothesized that the size of algae is an important feature, which ultimately determines the survival success during the passage through the digestive system, we found no relationship between survival rates of the algae and their cell sizes. However, the number of viable phytoplankton taxa increased in the larger cell-sized categories after digestion (Fig. 7). This increment was not typical for Dinoflagellatae, Euglenophyceae and Cryptophyta, even though most of these taxa consist of larger-sized species. The number of viable taxa from these groups decreased considerably as the digested material reached the hindgut. Despite the fact that these groups have different phylogenetic origin, they share common characteristics regarding their cell wall structure (intracellular coverings can be found in each of the enumerated taxa). It means that the structures, which make the cells more or less rigid, i.e., flattened cellulose-containing vesicles (Dinoflagellates), protainaceous plates (Cryptophytes) and the protainaceous pellicle (Euglenophytes), are formed beneath the outermost plasma membrane (Okuda, 2002). It seems that this otherwise evolutionary successful type of inner cell covering does not facilitate the survival of algal cells in the digestive systems of fish. However, investigation of potential dispersion of algae from the aspect of digestibility is not necessarily the most relevant approach. It is indisputable, that digestibility largely 
determines the amount of viable cells in the faeces of fish, i.e., the number of cells that can inoculate new habitats. Nevertheless, under favourable conditions, even a single cell can proliferate and build large populations in a new habitat. Thus, in the present context, the most important question is: which taxa are able to survive the passage through the digestive system of fish? Our investigations demonstrated that viable cells can be observed in the hindgut contents from each size group and each taxonomic group, except those algal groups that possess intracellular cell coverings.

Availability of algae to fish, i.e., which algae can be filtered effectively by Asian carps, also seemed to be an important question for us when planning this study. We can conclude that the plankton filtering of fish is apparently but not exclusively a size selective process, and even the smallest $(<10 \mu \mathrm{m})$ components of the phytoplankton can be found in the diet of Asian carps. Moreover, we established that there were taxa, which were not found in the lake water samples, but were observed in both foregut and hindgut content samples in variable proportions. Asian carps are able to filter several orders of magnitude larger water volume a day than what a researcher can check during a conventional sample analysis and this may explain the presence of more species in gut contents. These results support the view that distribution of phytoplankton size classes found in the hindgut does not reflect the menu offered to the herbivores but the leftovers after feeding (Sommer \& Stibor, 2002).

Because of the rapid downstream transport of algae (Hudon et al., 1996), colonization of the riverine ecosystems seems to be difficult for the newly arriving phytoplankton taxa. Although in the shallow areas the rivers are capable of retaining planktonic organisms (Reynolds, 2000), upstream dispersal needs the contribution of active vectors. Although, to our knowledge, there are no reports on the role of fish in algal dispersion in riverine systems, Asian carps can be effective vectors. Large population of these fish can develop in rivers and because of their feeding habits they have to come considerable distances independently of the 
flow direction. These fish can not only inoculate side arms, oxbows and other connecting water bodies, but can also modify the composition of the prevailing planktonic communities of these waters and thus can help the newcomers in the establishment populations.

In conclusion, we demonstrated that filter-feeding fish can harvest and disperse all algal taxa that are available in the ambient water, except for those few groups that possess intracellular cell coverings. However, this latter finding still requires further confirmation by additional experimental studies.

\section{References}

Bitterlich, G., 1985. Digestive enzyme pattern of two stomachless filter feeder, silver carp, Hypophthalmichthys molitrix Val., and bighead carp, Aristichthys nobilis Rich. J. Fish. Biol. 27: 103-112.

Borics, G., I. Grigorszky, J. Padisák \& S. Szabó, 2000. Phytoplankton associations in a small hypertrophic fishpond in East Hungary during a change from bottom-up to top-down control. Hydrobiologia 424: 79-90.

Borics, G., L. Nagy, S. Miron, I. Grigorszky, Z. László-Nagy, B. A. Lukács, L. G.-Tóth \& G. Várbíró, 2013. Which factors affect phytoplankton biomass in shallow eutrophic lakes? Hydrobiologia 714: 93-104.

Boros, G., A. Mozsár, Z. Vitál, S. A. Nagy \& A. Specziár, 2014. Growth and condition factor of hybrid (Bighead Hypophthalmichthys nobilis Richardson, 1845 x silver carp $H$. molitrix Valenciennes, 1844) Asian carps in the shallow, oligo-mesotrophic Lake Balaton. Journal of Applied Ichthyology-Zeitschrift für angewandte Ichthyologie 30: $546-548$. 
Brown, R. M., D. H. Jr. Larson \& H. C. Bold, 1964. Airborne algae: their abundance and heterogeneity. Science 143: 583-585.

Chrisostomou A., M. Moustaka-Gouni, S. Sgardelis \& T. Lanaras, 2009. Air-dispersed phytoplankton in a Mediterranean river-reservoir system (Aliakmon-Polyphytos, Greece). J. Plankton Res. 31: 877-884.

Cox, C. B. \& P. D. Moore, 1993. Biogeography: an Ecological and Evolutionary Approach. Oxford: Blackwell Scientific Publications pp. 326.

Cremer, M. C. \& R. O. Smitherman, 1980. Food habits and growth of silver and bighead carp in cages and ponds. Aquaculture 20: 57-64.

Datta, S. \& B. B. Jana, 1998. Control of bloom in a tropical lake: grazing efficiency of some herbivorous fishes. Fish Biology 53: 12-24.

Dong, S., D. Li, X. Bing, Q. Shi \& F. Wang, 1992. Suction volume and filtering efficiency of silver carp (Hypophthalmichthys molitrix Val.) and bighead carp (Hypophthalmichthys nobilis Rich.). Journal of Fish Biology 41: 833-840.

Ettl, H., 1978. Xanthophyceae. In: Ettl, H., J. Gerloff, H. Heynig (eds.), Süßwasserflora von Mitteleuropa, Band 3/1. Gustav Fischer Verlag, Stuttgart.

Förster, K., 1982: Conjugatophyceae. Zygnematales und Desmidiales (excl. Zygnemataceae). In: Huber-Pestalozzi, G. (ed.), Das Phytoplankton des Süsswassers: Systematik und Biologie, Band 16/8. Schweizerbart’sche Verlagsbuchhandlung, Stuttgart.

Gavel, A., B. Maršálek \& Z. Adámek, 2004. Viability of Microcystis colonies is not damaged by silver carp (Hypophthalmichthys molitrix) digestion. Algol. Stud. 113: 189-194.

Genitsaris, S., K. A. Kormas \& M. Moustaka-Gouni, 2011. Airborne algae and cyanobacteria: occurrence and related health effects. Frontiers in Bioscience E3: 772-787.

Hammer, O., D. A. T. Harper \& P. D. Ryan, 2001. PAST: Paleontological Statistics Software Package for education and data analysis. Palaeontol Electron 4(1): 9. 
Hampl, A., J. Jirasek \& D. Sirotek, 1983. Growth morphology of the filtering apparatus of silver carp (Hypophthalmichthys molitrix Val.) II. microscopic anatomy. Aquaculture 31: 153-158.

Herodek, S., I. Tátrai, J. Oláh \& L. Vörös, 1989. Feeding experiments with silver carp (Hypophthalmichthys molitrix Val.) fry. Aquaculture 83: 331-344.

Hofmann, G., M. Wermun \& H. Lange-Bertalot, 2011. Diatomeen in Süßwasser-Benthos von Mitteleuropa. A.R.G. Gantner Verlag. Koeltz Scientific Books, Königstein, Germany.

Huber-Pestalozzi, G., 1950. Das Phytoplankton des Süsswassers. Systematik und Biologie. Cryptophyceen, Chloromonadinen, Peridineen. In: Thiemannn, A. (ed.), Die Binnengewässer, Band 16/3. Schweizerbart’sche Verlagsbuchhandlung, Stuttgart.

Huber-Pestalozzi, G., 1955. Das Phytoplankton des Süßwassers. Systematik und Biologie. Euglenophyceen. In: Thienemann, A. (ed.), Die Binnengewässer, Band 16/4. Schweizerbart, Stuttgart.

Huber-Pestalozzi, G., 1961. Das Phytoplankton des Süßwassers. Systematik und Biologie. Chlorophyceae, Volvocales. In: Thienemann, A. (ed.), Die Binnengewässer, Band 16/5. Schweitzerbart'sche Verlagsbuchhandlung, Stuttgart.

Hudon, C., S., Paquet \& V., Jarry, 1996. Downstream variations of phytoplankton in the St. Lawrence River (Québec, Canada). Hydrobiologia 337: 1-26.

Istvánovics, V., A. Clement, L. Somlyódy, A. Specziár, L. G.-Tóth \& J. Padisák, 2007. Updating water quality targets for shallow Lake Balaton (Hungary), recovering from eutrophication. Hydrobiologia 581: 305-318.

Jancula, D., M. Mikovcova, Z. Adamek \& B. Marsalek, 2008. Changes in the photosynthetic activity of Microcystis colonies after gut passage through Nile tilapia (Oreochromis niloticus) and silver carp (Hypophthalmichthys molitrix). Aquacult. Res. 39: 311-314. 
Jennings, D. P., 1988. Bighead carp (Hypophthalmichthys nobilis): a biological synopsis. U. S. Fish Wildlife Serv. 88: 1-35.

Kolar, C. S., D. C. Chapman, W. R. Jr. Courtenay, C. M. Housel, J. D. Williams \& D. P. Jennings, 2007. Bigheaded carps: a biological synopsis and environmental risk assessment. American Fisheries Society Special Publication 33, Bethesda, Maryland.

Kolmakov, V. I., M. I. Gladyshev, E. S. Kravchuk, S. M. Chuprov, O. V. Anishchenko, E. A. Ivanova \& M. Yu. Trusova, 2006. Species-specific stimulation of cyanobacteria by silver carp Hypophthalmichthys molitrix (Val.). Doklady Biological Sciences 408: 223225.

Komárek, J. \& K. Anagnostidis, 1998. Cyanoprokaryota. Chroococcales. In: Ettl, H., G. Gärtner, H. Heynig \& D. Mollenhauer (eds), Süßwasserflora von Mitteleuropa, Band 19/1. Gustav Fisher, Berlin.

Komárek, J. \& K. Anagnostidis, 2005. Cyanoprokaryota. Oscillatoriales. In: Büdel, B., L. Krienitz, G. Gärtner \& M. Schagerl (eds), Süßwasserflora von Mitteleuropa, Band 19/2. Gustav Fisher, Jena.

Komárek, J. \& B. Fott, 1983. Das Phytoplankton des Süsswassers. Systematik und Biologie. Chlorophyceae (Grünalgen), Ordnung: Chlorococcales. In: Huber-Pestalozzi, G. (ed), Die Binnengewässer, Band 16/7. Schweitzerbart’sche Verlagsbuchhandlung, Stuttgart.

Krammer, K., 2003. Diatoms of the European Inland Waters and Comparable Habitats, vol.4, Cymbopleura, Delicata, Navicymbula, Gomphocymbellopsis, Afrocymbella. Edited by H. Lange-Berlot. Ruggell, Liechtenstein: A. R. Gantner Verlag.

Krammer, H. \& H. Lange-Bertalot, 1986-1991. Bacillariophyceae. In: Ettl, H., G. Gärtner, J. Gerloff, H., Heynig \& D. Mollenhauer (eds): Süßwasserflora von Mitteleuropa 2 (1-4). Gustav Fischer, Stuttgart. 
Lazzaro, X., 1987. A review of planktivorous fishes: their evolution, feeding behaviours, selectivities, and impacts. Hydrobiologia 146: 97-167.

Lewin, W. C., N. Kamjunke \& T. Mehner, 2003. Phosphorus uptake by Microcystis during passage through fish guts. Limnol. Oceanogr. 48: 2392-2396.

Lin, Q., X. Jiang, B.-P. Han \& E. Jeppesen, 2014. Does stocking of filter-feeding fish for production have a cascading effect on zooplankton and ecological state? A study of fourteen (sub)tropical Chinese reservoirs with contrasting nutrient concentrations. Hydrobiologia 736: 115-125.

Miura, A. \& J. Wang, 1985. Chlorophyll a found in feces of phytoplanktivorous cyprinids and its photosynthetic activity. Verh. Int. Ver. Limnol. 22: 2636-2642.

Moriarty, D. J. W., 1973. The physiology of digestion of blue-green algae in the cichlid fish, Tilapia nilotica. J. Zool. Lond. 171: 25-39.

Moriarty, C. M. \& D. J. W. Moriarty, 1973. Quantitative estimation of the daily ingestion of phytoplankton by Tilapia nilotica and Haplochromis nigripinnis in Lake George, Uganda. J. Zool. Lond. 171: 15-23.

Northcott, M. E. \& M. C. M. Beveridge, 1988. The development and structure of pharyngeal apparatus associated with filter feeding in tilapias (Oreochromis niloticus). J. Zool. Lond. 215: 133-149.

Okuda, K., 2002. Structure and phylogeny of cell coverings. Journal of Plant Research 115: 283-288.

Padisák, J., 2004. Phytoplankton. In: O’Sullivan, P. E. \& C. S. Reynolds (eds), The lakes handbook. Blackwell Science Ltd., Oxford: 251-307.

Popovsky, J. \& L. Pfiester, 1990. Dinophyceae (Dinoflagellida). In: Ettl, H., J. Gerloff, H. Heynig, D. Mollenhauer (eds), Süßwasserflora von Mitteleuropa, Band 6. Gustav Fischer Verlag, Stuttgart 
Porter, K. G., 1973. Selective grazing and differential digestion of algae by zooplankton. Nature 244: 179-180.

Porter, K., 1976. Enhancement of algal growth and productivity by grazing zooplankton. Science 192: 1332-1333.

Reynolds, C. S., 2000. Hydroecology of river plankton: The role of variability in channel flow. Hydrol. Proc. 14: 3119-3132.

Sampson, S. J., J. H. Chick \& M. A. Pegg, 2009. Diet overlap among two Asian carp and three native fishes in backwater lakes on the Illinois and Mississippi Rivers. Biol. Invasions 11: 483-496.

Smith, D. W., 1989. The feeding selectivity of silver carp, Hypophthalmichthys molitrix Val. J. Fish. Biol. 34: 819-828.

Sommer, U. \& H. Stibor, 2002. Copepoda-Cladocera-Tunicata: the role of three major mesozooplankton groups in pelagic foodwebs. Ecol. Res. 17: 161-174.

Stanier, R. Y., R. Kunisawa, M. Mandel, \& G. Cohen-Bazire, 1971. Purification and properties of unicellular blue-green algae (order Chroococcales). Bacteriol Rev. 35: $171-205$.

Starmach, K., 1985. Chrysophyceae und Haptophyceae. In: Ettl, H., J. Gerloff, H. Heynig, D. Mollenhauer (eds), Süßwasserflora von Mitteleuropa, Band 1. Gustav Fischer Verlag, Stuttgart.

Tátrai I., G. Paulovits, V. Józsa, G. Boros, Á. I. György \& J. Héri, 2009. Halállományok eloszlása és a betelepített halfajok állománya a Balatonban [Distribution of fish stocks and the stock of the introduced fish species in Lake Balaton]. In: Bíró, P. \& J. Banczerowski (eds), A Balaton kutatások fontosabb eredményei 1999-2009. MTA, Budapest: 129-141. [In Hungarian with English summary]. 
Tátrai, I., V. Istvánovics, L. G.-Tóth \& I. Kóbor, 2008. Management measures and long-term water quality changes in Lake Balaton (Hungary). Fundamental and Applied Limnology, Archiv für Hydrobiologie, 172: 1-11.

Tátrai, I., V. Józsa, Á. I. György, M. Havasi \& I. Szabó, 2006. A busa biológiai szerepének és hatásának vizsgálata a Balatonban [Investigation of the biological role and influence of silver carp in Lake Balaton]. In: Mahunka, S. \& J. Banczerowski (eds), A Balaton kutatásának 2005. évi eredményei. MTA, Budapest: 73-83. [In Hungarian with English summary].

Utermöhl, H., 1958. Zur Vervollkommnung der quantitativen phytoplankton-methodik. M. H. Int. Ver. Limnol. 9: 1-38.

Van den Hoek, C., D. G. Mann \& H. M. Jahns, 1995. Algae: an introduction to phycology. Cambridge University Press, Cambridge, UK.

Van Overeem, M. A., 1937. On green organisms occurring in the lower troposphere. Trav. Bot. Neerl. 34: 388-442.

Vörös, L., I. Oldal, M. Présing \& K. V.-Balogh, 1997. Size-selective filtration and taxonspecific digestion of plankton algae by silver carp (Hypophthalmichthys molitrix Val.). Hydrobiologia 342/343: 223-228.

Xie, P., 1999. Gut contents of silver carp, Hypopthalmichthys molitrix, and the disruption of a centric diatom, Cyclotella, on passage through the esophagus and intestine. Aquaculture 180: 295-305.

Zeng, Q., X. Gu \& Z. Mao, 2014. In situ growth and photosynthetic activity of Cyanobacteria and phytoplankton dynamics after passage through the gut of silver carp (Hypophthalmichthys molitrix), bighead carp (Aristichthys nobilis), and Nile tilapia (Oreochromis niloticus). Hydrobiologia 736: 51-60. 
520 Zhang, X., P. Xie \& X. Huang, 2008. Review of Nontraditional Biomanipulation. The Scientific World Journal 8: 1184-1196.

522

523

524

525

526

527

528

529

530

531

532

533

534

535

536

537

538

539

540 
542 Table 1.

543 Number of identified phytoplankton species in samples collected from Lake Balaton at the

544 vicinity of the nets used for fishing Asian carp on 5 occasions (April, May, June, September,

545 October) during 2013.

\begin{tabular}{llllll}
\hline & April & May & June & September & October \\
\hline Pennate diatoms & 11 & 9 & 20 & 4 & 11 \\
Centric diatoms & 4 & 6 & 6 & 4 & 5 \\
Filamentous blue-greens & 1 & 5 & 4 & 4 & 6 \\
Colonial blue-greens & 5 & 4 & 5 & 8 & 3 \\
Chlorococcales & 12 & 16 & 19 & 12 & 13 \\
Volvocales & 0 & 1 & 1 & 0 & 1 \\
Dinophyta & 2 & 1 & 0 & 1 & 0 \\
Desmidiales & 0 & 1 & 2 & 4 & 2 \\
Crysophyceae & 2 & 2 & 1 & 1 & 1 \\
Cryptophyta & 2 & 1 & 2 & 1 & 2 \\
Euglenophyta & 2 & 1 & 0 & 1 & 0 \\
Xanthophyceae & 0 & 1 & 1 & 0 & 0 \\
Total number of species & $\mathbf{4 1}$ & $\mathbf{4 8}$ & $\mathbf{6 1}$ & $\mathbf{4 0}$ & $\mathbf{4 4}$ \\
\hline
\end{tabular}

547 Table 2

548 Number of identified phytoplankton species collected from the foreguts (the anterior end of

549 intestines of the fish) of Asian carps on 5 occasions (April, May, June, September, October) 550 during 2013. 


\begin{tabular}{llllll}
\hline & April & May & June & September & October \\
\hline Pennate diatoms & 21 & 17 & 30 & 25 & 26 \\
Centric diatoms & 4 & 5 & 8 & 10 & 7 \\
Filamentous blue-greens & 3 & 6 & 6 & 6 & 5 \\
Colonial blue-greens & 8 & 8 & 8 & 10 & 8 \\
Chlorococcales & 17 & 21 & 29 & 22 & 27 \\
Volvocales & 0 & 0 & 1 & 1 & 0 \\
Dinophyta & 2 & 3 & 2 & 3 & 1 \\
Desmidiales & 2 & 2 & 2 & 3 & 4 \\
Crysophyceae & 2 & 0 & 1 & 0 & 0 \\
Cryptophyta & 1 & 2 & 1 & 0 & 1 \\
Euglenophyta & 9 & 4 & 6 & 4 & 10 \\
Xanthophyceae & 0 & 0 & 0 & 1 & 0 \\
Total number of species & $\mathbf{6 9}$ & $\mathbf{6 8}$ & $\mathbf{9 4}$ & $\mathbf{8 5}$ & $\mathbf{8 9}$ \\
\hline
\end{tabular}

559 Table 3

560 The list of all species, which occurred in the Lake Balaton, in the foregut and in the hindgut

561 samples during the 5 month (April, May, June, September, October) of 2013.

\begin{tabular}{lccc}
\hline Name of the species & Lake Balaton & Foregut & Hindgut \\
\hline Acanthoceras zachariasii & & $\mathrm{X}$ & \\
Aphanizomenon gracile & & $\mathrm{X}$ & $\mathrm{X}$ \\
Achnanthes minutissima & & $\mathrm{X}$ & $\mathrm{X}$ \\
Achnanthes sp. & $\mathrm{X}$ & $\mathrm{X}$ & \\
Amphora calumetica & & $\mathrm{X}$ & $\mathrm{X}$ \\
Amphora ovalis & & & $\mathrm{X}$ \\
Amphora sp. & $\mathrm{X}$ & $\mathrm{X}$ & \\
Amphora veneta & & & $\mathrm{X}$ \\
Anabaena sp. & $\mathrm{X}$ & & $\mathrm{X}$ \\
Aphanizomenon issatschenkoi & & $\mathrm{X}$ & $\mathrm{X}$ \\
Aphanizomenon sp. & $\mathrm{X}$ & $\mathrm{X}$ & \\
Aphanocapsa holsatica & & & $\mathrm{X}$ \\
Aphanocapsa incerta & & & $\mathrm{X}$ \\
Aphanocapsa conferta & & & $\mathrm{X}$ \\
Aphanocapsa delicatissima & & & \\
Aphanocapsa planctonica & $\mathrm{X}$ & $\mathrm{X}$ & $\mathrm{X}$ \\
Aphanocapsa sp. & $\mathrm{X}$ & $\mathrm{X}$ & $\mathrm{X}$ \\
Aphanothece sp. & $\mathrm{X}$ & $\mathrm{X}$ & $\mathrm{X}$ \\
Aulacoseira ambigua & $\mathrm{X}$ & $\mathrm{X}$ & $\mathrm{X}$ \\
Aulacoseira granulata & $\mathrm{X}$ & $\mathrm{X}$ & $\mathrm{X}$ \\
Aulacoseira granulata var. angustissima & $\mathrm{X}$ & $\mathrm{X}$ & $\mathrm{X}$ \\
Aulacoseira sp. & $\mathrm{X}$ & $\mathrm{X}$ & \\
Botryococcus braunii & & $\mathrm{X}$ & \\
Caloneis sp. & $\mathrm{X}$ & &
\end{tabular}


Carteria sp.

Centrales sp.

Ceratium hirundinella

$x$

$x$

$x$

X

Characium sp.

Chlamydomonas simplex

Chlamydomonas sp.

Chlorella sp.

Chlorococcales sp.

Choricystis minor

Chroococcus limneticus

Chroococcus minimus

Chroococcus planctonicus

Chroococcus turgidus

Closterium aciculare

Closterium acuminatum

Closterium acutum

Closterium acutum var. variabile

Cocconeis sp.

Coelastrum astroideum

Coelastrum microporum

Coelastrum pseudomicroporum

Coelastrum reticulatum

Cosmarium humile

Cosmarium sp.

Cryptomonas sp.

Cryptophyta sp.

Crysochromulina parva

Crysophyceae sp.

Cyanocatena sp.

Cyanodichtyon sp.

Cyclotella bodanica

Cyclotella meneghiniana

Cyclotella ocellata

Cyclotella pseudostelligera

Cylindrospermopsis raciborskii

Cylindrospermopsis sp.

Cymatopleura elliptica

Cymatopleura solea

$x$

X

$x$

$x \quad x$

$x$

$x \quad x$

$x$

$x$

$x$

$x$

$\begin{array}{lll}x & x & x\end{array}$

$x$

$\mathrm{X}$

Cymbella silesiaca

Cymbella elliptica

Cymbella minuta

Cymbella sp.

Dactyosphaerium jurisii

Dactyosphaerium sociale

Dictyosphaerium chlorelloides

Dictyosphaerium pulchellum

Dictyosphaerium tetrachotomum

Dinophyta sp.

Diploneis parma

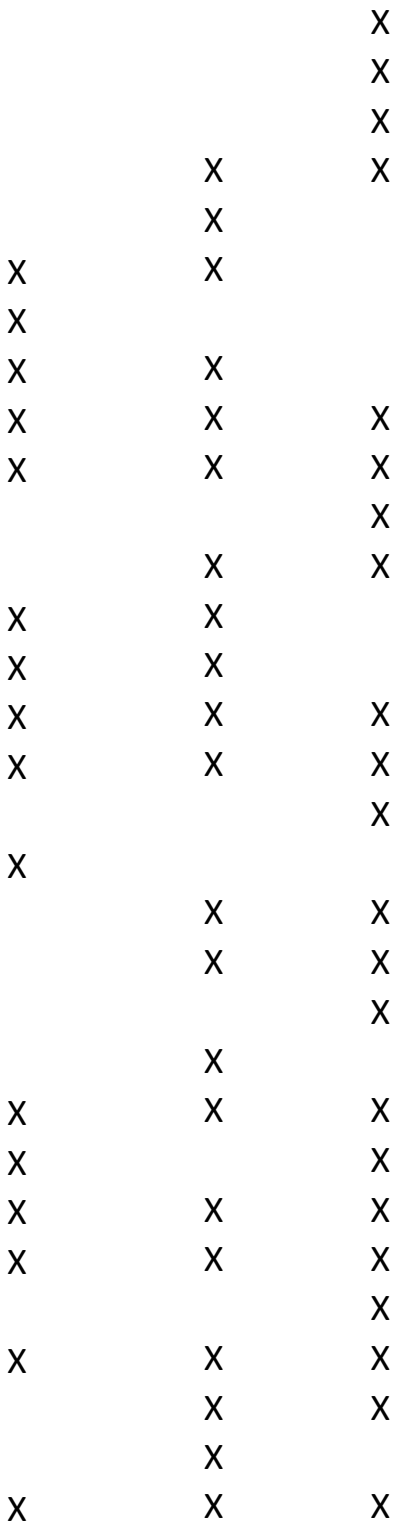


Dysmorphococcus sp.

Eucapsis sp.

Euglena acus

Euglena allorgei

$x$

Euglena oblonga

$x$

Euglena deses

Euglena gracilis

Euglena limnophila

Euglena mutabilis

Euglena oxyouris

Euglena pisciformis

Euglena spirogyra

X

Euglena texta

Euglena variabilis

Euglenoid sp.

Eunotia sp.

Eutetramorus fottii

Eutetramorus glabrum

$x$

Fragilaria capucina

Fragilaria construens

$x$

$x$

$x$

$x$

$x$

$x$

$x$

Fragilaria nitzschoides

Fragilaria parasitica

Fragilaria pinnata

Fragilaria sp.

Fragilaria ulna

Fragilaria ulna var. acus

Francea sp.

Gloeotila sp.

Gomphonema olivacea

Gomphosphaeria sp.

Gyrosigma sp.

Kirchneriella dianae

Kirchneriella irregularis

Kirchneriella obesa

Komvolophoron sp.

Lagerheimia balatonica

Lepocinclis fusiformis

Lepocinclis ovum var. dimido-minor

Merismopedia minutissima

Merismopedia tennuis

Micractinium pusillum

Microcoleus sp.

Microcystis aeruginosa

Microcystis viridis

$x$

$x$

$x$

$x$

$x$

$x$

$x$

$x$

$x$

$\begin{array}{ll}x & x \\ x & x\end{array}$

$x$

$x$

Microspora sp.

Monoraphidium contortum

Monoraphidium griffithii

Monoraphidium irregulare

$\mathrm{X}$

$x$

$x$

X

$x$

$x$

X

$x$

$x$

$\mathrm{X}$

$x$

$x$

$\mathrm{X}$

$x$

$x$

$x \quad x$

$x$

$x$

$x$

$x$

$x$

$x$

$x$

$x$

$\begin{array}{ll}x & x \\ x & x\end{array}$

$x$

$x$

$\begin{array}{ll}x & x \\ x & x\end{array}$

$x$

$x$

$x$ 
Monoraphidium komarkovae

Navicula radiosa

Navicula reticulata

Navicula rhynchocephala

Navicula sp.

Neidium sp.

Nephrochlamys sp.

Nephrochlamys subsolitaria

Nitzschia acicularis

Nitzschia amphibia

Nitzschia dissipata

Nitzschia constricta

Nitzschia graciliformis

Nitzschia gracilis

Nitzschia hantzschiana

Nitzschia hungarica

Nitzschia linearis

Nitzschia lorenziana

Nitzschia palea

Nitzschia sigmoidea

Nitzschia sp.

Oocystis lacustris

Oocystis marsonii

Oocystis parva

Oocystis solitaria

Oocystis sp.

Oscillatoria sp.

Pandorina smithii

Pediastrum boryanum

Pediastrum duplex

Pediastrum simplex

Peridinium cinctum

Phacotus lenticularis

Phacotus sp.

Phacus dangeardii

$x$

$x \quad x \quad x$

$\mathrm{X}$

$x$

$x \quad x \quad x$

$x \quad x$

$\mathrm{X}$

$x$

$x$

$\mathrm{X}$

$x \quad x$

$x$

$x \quad x$

$x$

$x$

$x \quad x \quad x$

$x$

$\begin{array}{lll}x & x & x\end{array}$

$x \quad x \quad x$

$x \quad x$

$\begin{array}{lll}x & x & x\end{array}$

$\begin{array}{lll}x & x & x\end{array}$

$x \quad x \quad x$

$x \quad x \quad x$

$x \quad x \quad x$

$x$

$\begin{array}{lll}x & x & x \\ x & x\end{array}$

$x \quad x \quad x$

$x$

X

Phacus megapyrenoides

Phacus skujae

Phacus sp.

Phacus wettsteinii

Phormidium autumnale

Phytomonadina sp.

Pinnularia viridis

Pinnularia sp.

Planktolyngbya capillaris

Planktolyngbya circinale

Planktolyngbya limnetica

Planktonema lauterbornii

Planktosphaeria gelatinosa

Pseudanabaena sp.

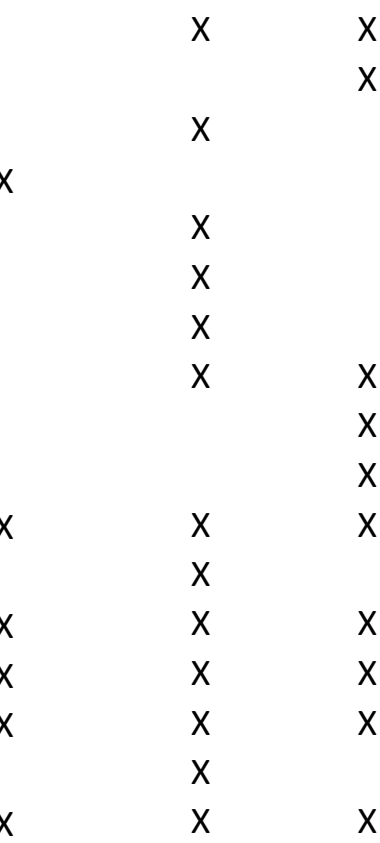


Quadricoccus ellipticus

Rhodomonas minuta

$x$

Rivularia sp.

Romeria elegans

Scenedesmus acuminatus

Scenedesmus acutiformis

Scenedesmus acutus

Scenedesmus arcuatus

Scenedesmus armatus

Scenedesmus balatonicus

Scenedesmus carinatus

Scenedesmus denticulatus

Scenedesmus dispar

Scenedesmus ecornis

Scenedesmus intermedius

Scenedesmus juvenilis

Scenedesmus maximus

Scenedesmus obtusos

Scenedesmus pleiomorphus

Scenedesmus quadricauda

Scenedesmus spinosus

Scenedesmus subspicatus

Schroederia robusta

Schroederia setigera

Schroederia sp.

Snowella lacustris

Snowella litoralis

Staurastrum chaetoceras

Stauroneis sp.

Stephanodiscus hantzschii

Stichococcus subtilis

Surirella brebissonii

Surirella robusta

Synechococcus elongatus

X

$x$

$x \quad x$

$x$

$x$

$x$

$x$

$x$

$x$

$x$

$x$

$x \quad x$

$x$

$x$

$x$

$x$

$x$

$x \quad x$

X

$x$

$x$

$x \quad x$

$x$

$x$

$x$

$x$

$x$

$x$

X

$X$

$x$

$x$

$x$

$x$

$\begin{array}{lll}x & x & x\end{array}$

$x \quad x$

$x \quad x$

$x \quad x$

$x \quad x$

$x \quad x \quad x$

Tetrachlorella sp.

Tetraedron caudatum

Tetraedron minutum

Tetrastrum staurogeniaeforme

Tetrastrum triangulare

Thalassiosira weissflogii

Trachelomonas oblonga

Trachelomonas volvocina

Trachydiscus lenticularis

Trachydiscus sp.

$x$

Ulothrix tenerrima

$x$

Willea sp.

Woronichinia naegeliana

Xanthophyceae sp.

$x$

$x$

$x$

$x$

$x$

$x$

X

X

X

$\begin{array}{ll} & x \\ & x \\ x & \\ x & X \\ X & \end{array}$


564 Number of viable taxa which were observed in the cultured (BG-11) hindgut samples in the 5

565 sampling months (April, May, June, September, October) during 2013.

\begin{tabular}{llllll}
\hline & April & May & June & September & October \\
\hline Pennate diatoms & 19 & 14 & 15 & 9 & 11 \\
Centric diatoms & 5 & 6 & 4 & 6 & 6 \\
Filamentous blue-greens & 6 & 5 & 5 & 7 & 8 \\
Colonial blue-greens & 12 & 13 & 11 & 10 & 12 \\
Chlorococcales & 26 & 30 & 33 & 19 & 29 \\
Volvocales & 0 & 1 & 1 & 1 & 2 \\
Dinophyta & 0 & 0 & 0 & 0 & 0 \\
Desmidiales & 0 & 0 & 1 & 2 & 3 \\
Crysophyceae & 0 & 1 & 0 & 0 & 0 \\
Cryptophyta & 0 & 0 & 0 & 0 & 0 \\
Euglenophyta & 0 & 0 & 1 & 1 & 1 \\
Xanthophyceae & 0 & 0 & 0 & 1 & 0 \\
Total number of species & $\mathbf{6 8}$ & $\mathbf{7 0}$ & $\mathbf{7 1}$ & $\mathbf{5 6}$ & $\mathbf{7 2}$ \\
\hline
\end{tabular}




\section{Legends for figures}

$3 \quad$ Fig. 1

4 An image of the filtering apparatus (gill raker) of hybrid Asian carp showing the inner surface

5 of the gill arch where the filtered material is collected and compressed prior to ingestion

6 (filtered matter highlighted by the white ellipse).

$7 \quad$ Fig. 2

8 The relative abundances of counted units (cells or colonies) in Lake Balaton.

$9 \quad$ Fig. 3

Relative abundances of the counted units (cells or colonies) in the foregut contents.

11

\section{Fig. 4 a, b}

Occurrence of the various algal taxa in the three types of samples. Letters above the columns indicate the similarities and/or the significant differences between the groups. (Identical letters indicate the lack of significant differences based on Kruskal-Wallis tests).

Fig. 5

Comparison of the algal composition (based on the number of species) of Lake Balaton, the foregut and the hindgut samples.

\section{Fig. 6}

Non-metric multidimensional scaling (nMDS) plots showing the ordination of the three types of samples (Lake Balaton: $\square$; foregut: x; hindgut: o), based on species occurrences and Jaccard similarity. 
Fig. 7

23 The number of phytoplankton taxa in the three size categories (1. category: $<10 \mu \mathrm{m}$; 2 . category: 10$24 \quad 40 \mu \mathrm{m}$; 3. category: $>40 \mu \mathrm{m})$. 